Relations industrielles

Industrial Relations

\title{
Zweig, Michael, The Working Class Majority: America's Best Kept Secret
}

\section{Frank Emspak}

Volume 55, numéro 4, 2000

URI : https://id.erudit.org/iderudit/051369ar

DOI : https://doi.org/10.7202/051369ar

Aller au sommaire du numéro

Éditeur(s)

Département des relations industrielles de l'Université Laval

ISSN

0034-379X (imprimé)

1703-8138 (numérique)

Découvrir la revue

Citer ce compte rendu

Emspak, F. (2000). Compte rendu de [Zweig, Michael, The Working Class Majority: America's Best Kept Secret]. Relations industrielles / Industrial Relations, 55(4), 795-797. https://doi.org/10.7202/051369ar

Tous droits réservés (C) Département des relations industrielles de l'Université Laval, 2000
Ce document est protégé par la loi sur le droit d'auteur. L'utilisation des services d'Érudit (y compris la reproduction) est assujettie à sa politique d'utilisation que vous pouvez consulter en ligne.

https://apropos.erudit.org/fr/usagers/politique-dutilisation/ 
l'instar du paysan en lutte avec la terre, que nous disposons de la capacité d'œuvrer à notre perte en ce combat anarchique : "Contre ces tempêtes intérieures, la seule défense de l'individu est de bien organiser son temps » (p. 141). Puis, à l'aide de Max Weber, il explique comment l'homme accepta de travailler à la sueur de son front dans l'espoir d'une gratification différée. L'éthique protestante incita à l'épargne et nullement à la consommation et par le travail, l'homme devait pouvoir prouver aux autres et à l'Autre sa valeur morale (p. 147).

Le véritable travail en équipe devrait favoriser des attentions mutuelles plutôt que l'automutilation individuelle. Sennett souligne qu'il n'en est pas ainsi parce qu'il ne s'agit vraiment pas d'un travail d'équipe mais de simples regroupements superficiels où l'acte de communication importe davantage que les faits communiqués. Il conclut alors en termes quelque peu alarmistes ce passage au néocapitalisme : «Quittant le champ de la tragédie, les relations humaines tournent à la farce » (p. 149).

Finalement, Richard Sennett explique que l'action incontinente du néocapitalisme ne pourrait être contenue que lorsque l'on saura répondre raisonnablement à cette double question : «quelle valeur représente l'entreprise pour la collectivité, en quoi elle sert les intérêts civiques, plutôt que son seul registre des pertes et profits $»$ (p. 194). Nous devons reconnaître que la lecture de cet ouvrage, Le travail sans qualités ne pourrait qu'enrichir et stimuler la réflexion de l'étudiant en relations industrielles. De même en serait-il pour toute personne qui s'intéresse vraiment aux questions du travail et surtout, à la personne même du travailleur.

Fernand Morin Université Laval

\section{The Working Class Majority: America's Best Kept Secret}

by Michael ZWEIG, Ithaca, N.Y.: ILR Press, 2000, 198 pp., ISBN 0-8014$3637-0$.

TINA: "There is no alternative." Margaret Thatcher popularized the phrase 20 years ago, and conservatives throughout the world took it up. The genius of Thatcher and Reagan lay in their successful ability to mobilize the rich and the corporate elite to act consciously and more publicly in their own narrow interests. Increasingly the advocates of TINA were able to ally with sections of the middle class and project the image that they - not the working classes - were the majority.

Intellectuals also took up the cry. Hundreds of academic works appeared describing the folly of socialism, the negative effects of unions, and the debilitating effects of welfare. The research was buttressed by claims that the working class, which might have needed unions in the past, no longer existed or, if it did, it was a new working class different from the old.

Unfortunately for working people all over the world, their erstwhile allies also accepted the idea that the old structures of workers' power were no longer needed. Even more unfortunate, many labour leaders also seemed to believe the TINA theory. In the political world, and especially in the U.S. and Great Britain, the result was a sharp move to the right by the Democratic and Labour parties.

While there are many explanations for the decline of organized labour, one aspect of the decline must surely be a disintegration of belief. If people no longer believe that there is a working class with distinct interests, then they are demobilized. It is also important to note 
that within the labour movement advocates of a class-based view of the world faced severe political repression. Business unionists within the labour movement, especially in the United States, succeeded in marginalizing most people who would mention the word "class." As a result, by the mid-1990s labour leaders in many capitalist countries had accepted the ideological foundation of TINA. Or, as some labour leaders finally recognized, one class (the capitalists) was fighting the class war while many workers did not think there were classes.

Now along comes The Working Class Majority by Michael Zweig. This seminal work demolishes step by step the mistaken assumptions held by many people about class. As Zweig takes the reader through a discussion of power, numbers, status, wealth, and function, he brings the reader along with him. The strength of this book is that it is not a lecture, but rather a discussion with the reader. At the end of each chapter, the points the author makes seem almost self-evident.

Zweig's most important contribution is to move the discussion of class to an understanding that the concept refers to one's function and one's place within society. In the author's words: "The book makes three basic points... First economic classes exist in U.S. society.... Second, class has a pervasive influence on the way we live, work and think.... Third class has a great influence on politics..." (p. 2).

The book has nine pithy chapters and a valuable appendix entitled "Working Class Resource Guide." Chapter One introduces the reader to the class structure in the United States. Chapter Two, entitled "What We Think about When We Think about Class," is focused on how workers think about their class identity. The chapter includes discussions about consumerism, the Cold War and working class ideology. In Chapter Three, Zweig returns to the theme of the centrality of class, before moving on to a discussion of the "underclass" in Chapter Four.

Chapters Four and Five are more focused on how one class has manipulated and used culture and race to substitute its political agenda for an agenda that would meet the needs of working people. More than the other chapters, these chapters are focused on political issues within the American context. Chapter Four deals specifically with the creation of the idea of an "underclass," meaning poor, especially non-white workers, who are then defined as "other" and thus a threat to working people. Conservatives defined the means to defeat that "threat" via successful attacks on the social safety net as it existed in the United States prior to 1980 . Zweig's contribution to the discussion is to show that the so-called underclass does not really exist. Poor people are just other workers out of a job (p. 86ff). Understanding that the so-called underclass is a political construction, not an economic one is a big step forward. Chapter Five, entitled "Looking at Values-Family and Otherwise," also challenges the American right wing's devotion to "family values" at the expense of affordable child care, day care, and medical care.

Chapters Six, Seven and Eight bring together the information provided in the first five chapters. The focus of these chapters is the working class and power - political and economic - and how to win it. The continuity of the struggle for power is evident when Zweig notes (Chapter Seven "Power and Globalization") that workers have been dealing with the issue of capital mobility "as long as owners have moved business from one city to another" (p. 141). Zweig goes on to detail how workers can respond to run-away shops and argues that the current internationalization of production may pave the way for the development of a truly international workers' movement. In Chapter Nine, Zweig continues his analysis of power 
focusing on the need for workers to use government as a necessary lever to control international capital mobility. Here Zweig points out that, rhetoric aside, the "capitalist class has not abandoned the field, thinking government is irrelevant. They are actively looking for answers that solve their needs" (p. 165). Zweig urges workers to do the same and make the policies and procedures of government a contested terrain.

In general, then, Mike Zweig takes us from a concept of class measured in terms of income to a view of class measured by what one does, and one's power over others. When this analyses is complete it becomes clear that the great majority of Americans belong to the working class.

Once it is clear that the majority of Americans are indeed workers in the sense of power and economic relationships, then the idea of self-conscious interests becomes easier to see. Looking at the world through the "lens of class" allows people to see the real distribution of power and wealth. Understanding the sources of power allows one to see how to change the organization of society to meet the needs of the working class majority.

A strength of the Zweig book is to demonstrate that the so-called new economy is creating an expanding working class, not a shrinking one. This insight is important for it allows one to think about alternatives to the current dominant ideology. If the working class is indeed growing, then what is being done to address the needs of that class?

Given the events during the past year in Seattle, Washington, Prague and elsewhere, the chapter on power and globalization seems to be particularly on target. In this respect, the author argues for enforceable international (and national) labour standards. Zweig returns again and again to the issue of who will enforce the standards, or indeed create them in the first place. He concludes that "these demands must come from a labour movement no longer limited to national boundaries" (p. 147).

Many of us saw the beginning of that movement in Seattle last year. We are seeing the continuation of it with the increasingly frequent and well-organized demonstrations against NAFTA and the WTO. Most importantly, slowly but surely we are seeing the creation of an alternative. This alternative is being created by the working class majority the very class that was supposed to have disappeared.

The Working Class Majority is a book about the United States, but the concepts it develops are universal. Readers in other countries will be able to see the parallels between their countries and the U.S. But most important of all, Zweig's basic analysis of class will help all workers to develop an alternative to TINA.

\author{
Frank EMspak \\ University of Wisconsin
}

